\title{
Supply and Demand of a Forest Biomass in Application to the Region of South-East Finland
}

\author{
Antti Karhunen, Mika Laihanen, Tapio Ranta
}

LUT Energy-Bioenergy Technology, Lappeenranta University of Technology, Lappeenranta, Finland.

Email: \{antti.karhunen, mika.laihanen\}@lut.fi

Received November $3^{\text {rd }}, 2011$; revised December $1^{\text {st }}, 2011$; accepted December $9^{\text {th }}, 2011$

\begin{abstract}
In Finland it is estimated that forest biomass will be the main source of bioenergy when meeting the national target: $38 \%$ renewable from total energy consumption by 2020 . This target must become concrete for regional and local level participators of a forest industry and actions should take place in large combined heat and power generation (CHP) plants, district heating plants and independent heating systems. In energy production replacing fossil fuels with renewable energy is reasonable in many cases. However, there are usually doubts about the availability and security of supply of forest biomass. The aim of this study is to introduce a systematical method for analyzing the availability and demand of forest biomass in regional and local level. This study introduces an objective method for analyzing local possibilities on where and how much the use of forest biomass could be increased. By replacing use of fossil fuels with renewable and domestic energy sources carbon dioxide $\left(\mathrm{CO}_{2}\right)$ emissions and dependency on imported fossil fuels can be reduced. Utilization of biomass creates also local employment on energy sector.
\end{abstract}

Keywords: Forest Biomass; Energy Production; Energy Consumption

\section{Introduction}

The EU target for renewable energy by 2020 is $20 \%$. Each member country has their own targets and for Finland the share of renewable energy sources has to be $38 \%$ of total energy consumption by 2020 and $20 \%$ for transport fuels. In 2010 Finland's total energy consumption was some $400 \mathrm{TWh}$ and the share of renewable energy sources was $26 \%$ (Figure 1) [1].

Today the largest share of renewable energy in Finland is produced by forest industry with black liquor and other woody by-products such as bark. The share of black liquor from Finland's total energy consumption is annually some $10 \%$ depending on production level of pulp Indus-

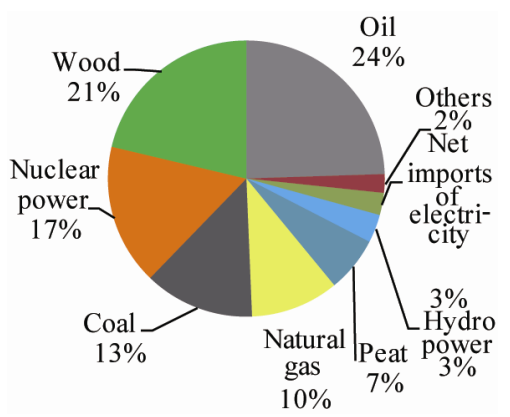

Figure 1. Total energy consumption of Finland in 2010, 401 TWh [1]. try [1].

Meeting the demanding share of $38 \%$ by 2020 means that the volume of Finnish pulp industry must maintain at the current level and the use of forest fuels should increase as it has done all the 21st century (Figure 2).

In 2010 the use of forest biomass was $13.8 \mathrm{TWh}$ equal to 6.9 million solid cubic meters $\left(1 \mathrm{solid} \cdot \mathrm{m}^{3} \approx 2 \mathrm{MWh} \approx\right.$ $7.2 \mathrm{GJ})$. The national target for the use of forest biomass in 2020 is $27 \mathrm{TWh}\left(13.5\right.$ million solid $\left.\cdot \mathrm{m}^{3}\right)$, which means that the use of it has to double by 2020. It is estimated that annual theoretical potential of forest biomass is some 30 million solid $\cdot \mathrm{m}^{3}$ in Finland which means that national forest biomass targets are achievable [2,3].

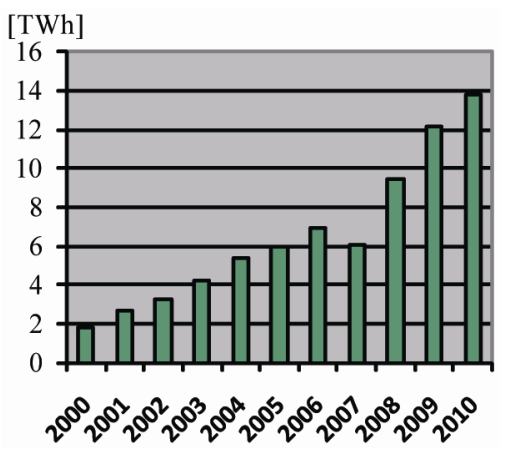

Figure 2. Use of forest biomass in Finland 2000-2010 [2]. 
Before national targets become concrete actions towards more renewable community has to be done in regional and local level. National policies, taxation and prices of fuels are some of the driving forces for energy producers and end users when evaluating the profitability of energy production.

When increasing the national and regional share of renewable energy sources one of the most influential actions is investing on large scale solid fuel fired CHP power plants. The amount of forest fuel and other solid biomass consumed annually in large CHP power plant could be some $0.1-1.0$ million solid $\cdot \mathrm{m}^{3}$ per plant. In local level the impact of smaller district heating plants, detached houses and other real estates is not as effective as larger CHP-plants but all improvement on local trade and welfare will lead regions towards national and EU targets.

In Finland coal, oil and natural gas-combusted district heating systems were constructed mainly in the 1960's and 1970's. In the future the structure of energy supply will go through a change and the demand of forest fuel will increase when the major cities-e.g. Helsinki, Tampere and Turku - in Finland are trying to find alternatives for their heat and power production. Elsewhere large scale CHP capacity already is widely converted for solid fuels such as biomass and peat. In smaller units, e.g. district heating plants in municipalities and detached houses, the demand of renewable energy will also increase especially because of rising prices of electricity and oil.

All these upcoming changes concerning the use of renewable energy sources and especially forest biomass will offer business opportunities e.g. for local bioenergy participants and forest owner. Before launching new entrepreneurship, basic knowledge of local possibilities and threats should be taken under consideration. Local result can be illustrated clearly for local decision makers.

\section{Approach}

The aim of this study is to introduce a systematical method for analyzing the availability and demand of forest fuel in local and regional level. By this method EU and national renewable energy sources (RES) utilization targets can be brought to local and regional level for all participants in the field of bioenergy.

This study focuses on a method for combining the availability and end-use of forest biomass. Study is constructed in a universally applicable way to define local potentials for increasing the use of forest biomass. Final consumption of forest biomass will be analyzed plantspecific and compared with the local availability. This creates a balance which indicates the sufficiency of the local forest biomass resources and current and potential use of it. In this study forest biomass is divided between logging residues, stumps and small diameter energy wood. These materials cannot be utilized as raw material in forest industry.

The method indicates single power plants were the use of forest fuels could be increased and the areas were forest fuels could be supplied for these end users. Results of this study concrete national targets for decision makers in regional and local level and give an objective overview about the possibilities and threats over the region under discussion.

The study was conducted in two main phases. First phase was to settle the current and potential end-users of forest biomass and to gather data about the amounts of forest biomass these plants are using today or could use without any investments on new combustion technology or unloading equipment. Also the structure of regional energy supply needs to be mapped when investigating the potential end-users for forest biomass. Second phase was to gather data about the local and regional availability of forest biomass from the area under examination.

Earlier studies in Finland concerning the subject are basically made case-specifically or in national level for different organizations. They are usually executed by Metsäntutkimuslaitos (Metla) [4] and Pöyry Energy [5,6]. These earlier studies have focused separately on the availability of forest biomass and for the use and potential use of all wood fuels. This study will introduce more local approach for the matter by combining precise local knowledge of end-use and availability of forest biomass. The method also introduces the supply-based availability and the potential use of forest biomass in regional and local level. Method is universally applicable and it gives an excellent overview of the region under discussion. Being aware of local forest biomass resources and potential end users will be beneficial background information for local participants and decision makers.

Following chapters will introduce the method more detailed on how to construct a model of local and regional forest biomass resources and potentials.

\subsection{Regional Use of Forest Biomass}

The regional use and potential for increasing the use of forest biomass is profitable information for both local level energy end-users and energy suppliers. Updating and bringing this information into local level also concretes the national RES-targets for local decision makers, investors and energy producers who usually should have the best possibilities to improve local renewable energy production.

In this study the initial data concerning the use of forest biomass was gathered plant-specific. This point out directly the places where demand for forest biomass cur- 
rently exist and where replacing fossil fuels with renewable energy sources could be technically and economically feasible.

Regional use of forest biomass was divided to three different categories:

1) Current use of forest biomass in existing heating and power plants;

2) Potential use of forest biomass in existing solid fuel fired plants and;

3) Potential use of forest biomass by investing on combustion and fuel handling technology.

First phase was to settle the current users and the annual use of forest biomass in the area under discussion. This phase can be conducted through national and regional statistics and by contacting directly the forest biomass users. The most usable information about the current use of primary energy sources in different regions can be gathered by the regional energy balance which indicates the structure of whole energy supply [7].

The second phase consisted of mapping the suitable existing plants which today are already using solid biomass and other solid fuels, e.g. forest industry by-products, recycled wood, peat, agro biomass, etc. These plants could basically start using forest biomass because of existing fuel handling systems and combustion technology. However, the use of forest industry solid byproducts such as bark, cutter chips and sawdust is generally not alternative for forest biomass because by-products are the cheapest option for forest industry's energy production and they need to be disposed anyway.

The third phase was to point out the new potential targets where the use of forest biomass could be feasible by investing on new combustion technology and on solid biomass handling and unloading equipment. These plants could be basic load heating and power plants running today for example on natural gas or coal. Reserve power and peak load capacity of communities and industry were excluded because of high investment cost and usability. Also industry processes where using raw solid biomass would be impossible were excluded, e.g. need for gasification etc.

Fourth possible category could be futures energy scenarios where structural and environmental changes are taken into account more carefully.

Below are pointed out main hypotheses when evaluating the potential use of forest fuels $[7,8]$.

- Structure of energy production and demand of energy is at the same level.

- The current plant-specific use of forest biomass in the region under discussion must be specified.

- Mapping the potential users for forest biomasscurrent and potential.

- CHP-plants constructed in the 21st century are often able to use up to $70 \%$ biomass (forest fuel, by-prod- ucts etc.) and $30 \%$ e.g. peat.

- Older CHP-plants could use up to $60 \%$ biomass and $40 \%$ peat.

- Smaller solid fuel based basic load heating plants $\left(<10 \mathrm{MW}_{\text {fuel }}\right)$ could run on $100 \%$ biomass.

- Smaller fossil fuel based basic load heating plants $\left(<10 \mathrm{MW}_{\text {fuel }}\right)$ could be converted to run on $100 \%$ biomass. Investments on solid fuel boiler and biomass unloading equipment are needed.

In this study the focus on increasing the use of forest biomass is in basic load district heating plants and CHPpower plants.

Local farm-scale energy production, larger real estates and detached houses $\left(<0.5 \mathrm{MW}_{\text {fuel }}\right)$ which are using and could use forest fuels were excluded from the study because of large number of the units. The share of smallscale use from total consumption of forest biomass is usually some $5 \%$ to $10 \%$ depending on the region. This can be evaluated through statistics.

Condensation power was also excluded from the study because the use of crude biomass is not at the time economically feasible in condensation power plants. However, in the future, for example the use of biocoal could become more profitable and it could replace fossil coal in condensation power plants and industrial processes. Gasified biomass could also be one option for replacing natural gas in energy production and in lime sludge kilns.

In this study end use of forest biomass was divided between large-scale use in cities power plants and smallscale use in municipalities heating plants. Larger CHP power plants have wider fuel mixture which enables them to use logging residues and stumps gathered from final felling. More homogenous small diameter energy wood is more suitable for local district heating plants.

The hypotheses represented previously must always be adapted for the local circumstances and markets. The hypotheses represented in this study are best applicable e.g. for Finland and Northern Europe.

\subsection{Regional Availability of Forest Biomass}

Regional availability indicates forest fuel potentials and resources in municipalities and provinces and brings the potentials more concrete to local level.

In this study the availability of forest fuels-logging residues, stumps and small diameter energy wood-is analyzed by using regional logging statistics (from previous years) and logging plans (for becoming years). Because of yearly variation in loggings it is most effective to use average quantities.

Logging statistics by municipality can be provided by Finnish Forest Research Institute and logging plans by Finnish Forestry Centre. Logging plan is usually a bit higher than the yearly felling and it represent the maxi- 
mum potential for regional availability of energy wood. The amount of energy wood could be calculated by following factors (Table 1). These factors are based on different studies and on local practical experiences.

Logging residues and stumps are basically gathered from regeneration felling and small diameter energy wood from young forest restoration and first thinning. In this study logging residues are collected from spruce, pine and birch, even though the share of birch from final felling is usually relatively small. The yield of logging residues is largest from spruce dominated regeneration felling. The stumps will be lifted from spruce and pine. Small diameter energy wood is usually mixture of all species, dominated by deciduous trees.

Hypothesis for small diameter energy wood is that the amount of pulpwood in the region should remain on its current level and no pulpwood sized wood will be used as an energy wood.

For evaluating the most realistic availability of energy wood in the region, the availability will be represented with four different levels. These levels take account e.g. economical and technical limitations and the forest owners' willingness to supply energy wood which has a quite large effect on the availability. Supply-based availability is the latest innovation when evaluating the most realistic regional availability of forest biomass. Different levels of availability are represented below [12-14].

1) Theoretical availability: theoretical amount of all forest fuel fractions (logging residues, stumps and small diameter energy wood).

2) Technical availability: recovery percent in harvesting for logging residues is $70 \%$, stumps $90 \%$ and for small diameter energy wood $90 \%$.

3) Techno-economic and -ecological availability: 70\% of all forests to be cut qualify the economical and ecological requirements for logging residues, $60 \%$ for stumps and $90 \%$ for small diameter energy wood.

4) Supply-based availability: forest owners willingness

Table 1. Factors used for evaluating the yield [solid $\cdot \mathrm{m}^{3}$ energy wood $/ \mathrm{solid} \cdot \mathrm{m}^{3}$ industrial $\left.\mathrm{wood}\right]$ and energy content [MWh/solid $\cdot \mathrm{m}^{3}$ energy wood] of forest biomass $[5,9,10,11]$.

\begin{tabular}{lccc}
\hline & Logging residues & Stumps & $\begin{array}{c}\text { Small diameter } \\
\text { energy wood }\end{array}$ \\
\hline $\begin{array}{l}\text { Spruce } \\
\text { Yield }\end{array}$ & 0.23 & 0.28 & - \\
Energy content & 2.03 & 2.34 & 1.91 \\
$\quad$ Pine & 0.42 & 0.31 & - \\
Yield & 2.10 & 2.13 & 1.96 \\
Energy content & & & - \\
$\quad$ Birch & 0.20 & - & 2.31 \\
Yield & 2.46 & - & \\
Energy content & & & \\
\hline
\end{tabular}

to sell energy wood is $65 \%$ for logging residues, $50 \%$ for stumps and $80 \%$ for small diameter energy wood.

Ecological limitation and sustainability of utilization should be taken into account in harvesting regulations and recommendations.

When optimizing forest economy thinning has an important role in forestry. It could also be possible to have subsidiaries from the government for these actions. This is why availability of small diameter energy wood is higher compared to logging residues and stumps.

\section{Scientific Innovation and Relevance}

This study creates a systematic and analytic method to evaluate local potentials and resources of forest biomass. Study introduces simple way for pointing out local possibilities and limitations on increasing the use of forest biomass.

In some cases combining energy technology to forestry could be quite challenging. One main points of this study is to highlight these matters and to familiarize them for local level participants such as local councilors, forest owners, investors, energy producers and forest biomass suppliers.

Knowing forest biomass potentials and resources are key factors when bringing the national RES-targets to local level. Today in many cases it is also economical to convert fossil fuel based heating and power plants for domestic biofuels, mainly because of rising prices of fossil fuels. Government subsidiaries and taxation could speed up this development.

Applying the study to local and regional level brings out local possibilities and treats concerning the use and availability of forest fuel. Results of this study enable dividing the current and potential use of forest biomass individually plant by plant and to evaluate the availability of forest biomass in different parts of the area. This is useful information for the decision makers and participants working in the field of bioenergy. e.g. participants are able to map market potentials and to point out possible targets for energy entrepreneurs and others. This could lead for new business opportunities for example in supply and end use of forest biomass and in subcontracting and service consulting.

\section{Results of the Study}

The results of this study represent the balance between local availability of forest biomass and current and potential use of it. Combining the use and availability gives an overall look for possibilities and threats over the forest fuel markets. Results represent the sufficiency of local resources and reflect local demand trends for the future. Results offer good basis for further analyses and they enable e.g. evaluation of new business opportunities, 
need for labor and machinery and revenue of forest biomass sector.

Next chapters will introduce the results of this study and benefits of them more detailed. Later results will be presented through a case example from the region of South-East Finland.

\subsection{Current and Potential Use of Forest Biomass in Regional and Local Level}

By gathering information about current and potential use and users of forest biomass, can be constructed a database which contains specific and unified information needed in local level. Maybe the best way to assort this information is to use regional energy balance which contains all primary energy consumption.

Current use of forest biomass represents the present status of local operation models (supply chains, entrepreneurship, markets). It gives also an overall look to areal opportunities. Plant specific use of forest biomass offers background information used in local level and it focuses the use to different regions and areas. By this information can be seen where and how much forest biomass is already used and how the energy production and supply is managed. These operation models can be copied and used in different regions.

Potential use of forest biomass was divided between possible use in existing solid fuel based plants and potential use by investing on solid fuel combustion and handling technology. Existing heating and power plants which are already using solid fuels (by-products, peat, agro biomass, etc.) are usually able to start using or increase the use of forest biomass which offers opportunities for forest biomass suppliers to extend their trade.

Potential use of forest biomass through investments represents the potential areal forest biomass markets with current primary energy consumption. This is the maximum use potential of forest biomass in region when all existing heating and power plants are taken into account. In this study refining of forest biomass-e.g. biocoal, biodiesel and gasification - was excluded, but in the future it should be taken into account.

The current and potential use of forest biomass can be divided between regions and municipalities because of plant specific results. This is an asset when focusing actions on increasing the use of renewable energy. Actions and development can be directly pointed to particular plants and optimize the supply routes of forest biomass. Local level knowledge is also vital for decision makers, investors and other participants when considering ways to improve local energy self-sufficiency with competitive renewable fuels.

\subsection{Availability of Forest Biomass in Regional and Local Level}

The availability of forest biomass was divided to four different categories by noticing economical, ecological and technical limitations. The major addition compared to previous studies concerning the availability of forest biomass was to include forest owners' willingness to offer different energy wood fractions into market. This can be affected by regulations, forest treatment planning, recommendations and informing forest owners.

To equalize the yearly variation in loggings availability should be evaluated by the average from yearly data. Useful initial data are local commercial loggings and logging plans. Logging plan usually gives some 20 to 25 percent higher results depending on the area under discussion. This is because commercial fellings do not usually follow the logging plan and yearly variation can be significant.

Choosing the initial data depends on the use of results. Logging plan is more suitable for long-term evaluating when is estimated that the availability of forest fuels will slightly increase. Commercial fellings are more usable when examining current availability and situation of forest biomass market. Volume of commercial fellings affects directly to availability of logging residues and stumps.

Theoretical availability is one that set up the upper limit for local forest biomass resources. In practice this amount of energy wood cannot be harvested but by taking into account factors reducing the availability can be obtained more realistic estimations about the availability. In this study the techno-economic and -ecological availability is some $50 \%$ from theoretical availability and the supply-based potential is only one third of it. These results represent current situation well in regions where loggings are made in time and the demand for industrial wood and energy wood exist.

However the current situation could change in the future and availability of forest biomass could increase. Following list contains the main factors affecting most on availability of forest fuels:

- volume of industrial wood loggings,

- cost of harvesting,

- taxation and subsidies of renewable and fossil fuels,

- functionality of markets,

- prices of alternative fuels,

- forest owners willingness to sell energy wood,

- regulations and recommendations,

- certification rules for forest biomass energy use.

\subsection{Balance between Use and Availability of Biomass in South-East Finland}

The most illustrative way to represent availability and 
use of forest biomass is to use forest biomass balance. It indicates sufficiency of regional and local forest fuel resources compared to current and futures potential demand of forest biomass. Results can be represented on a map or in charts. On map, municipalities with negative balance-higher demand than supply — can be illustrated e.g. with red color and areas with positive balance can be illustrated e.g. with green color. Map indicates directly areas with highest demand of forest fuel and areas where forest fuel can be harvested and supplied for heating and power plant or refining.

The results of this study can be used for evaluating the suitability of forest fuels for different users. It is important to optimize the use by directing most suitable fuel for most suitable end user, meaning that the quality, moisture and size of chips must be proper and the supply range cannot be too long. In Southern Finland economically reasonable supply radius for larger CHP-plants is usually some 50 to $100 \mathrm{~km}$. For smaller heating plants radius is shorter, usually less than $40 \mathrm{~km}$.

In the future the additional value for refining forest biomass could become more significant. This will increase the solvency of end users and redirect the forest biomass for new kind of refining such as biodiesel production, gasification or torrefaction. Large-scale biorefineries could utilize annually more than 1.0 million $\mathrm{m}^{3}$ (2 TWh) raw materials.

The results of this study can be represented by tables, charts and maps depending on the accuracy needed and the purpose of use. The results are illustrative for different participants because different areas can be separated from results and use for local needs.

\subsection{Case Example, Region of South-East Finland}

Case example of the study focuses on the regional use and availability of forest biomass in South-East Finland. South-East Finland is known as one of Europe's largest forest industry concentrations with the annual raw wood consumption of 15 to 20 million solid $\cdot \mathrm{m}^{3}$, in 201019.6 million $\mathrm{m}^{3}$. This is little less than $30 \%$ of Finland total raw wood consumption, which was some 70 million sol$\mathrm{id} \cdot \mathrm{m}^{3}$ in 2010 [15]. The share of renewable energy sources in South-East Finland is about $60 \%$ from total primary energy consumption (traffic excluded) [7]. The major cities of the region are Lappeenranta, Kotka and Kouvola which all have large solid fuel based CHPpower plants.

Following paragraphs and figures will shortly sum the results of case-example. Figure 3 represents the development of forest fuel consumption in South-East Finland. These results take account the small-scale use of forest biomass which share is some $5 \%$ of total consumption [2].

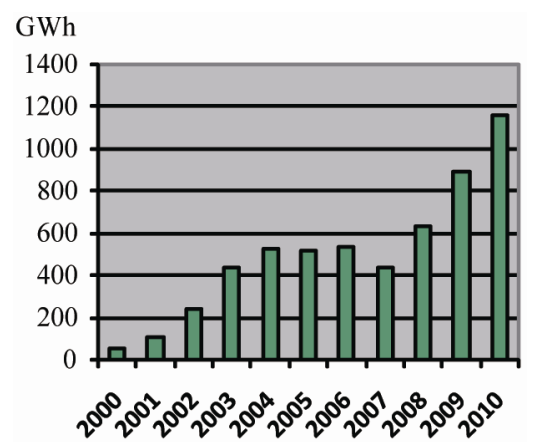

Figure 3. Use of forest biomass in South-East Finland 20002010, GWh [2].

The use of forest biomass has increased rapidly in the 21 st century due to increased prices of fossil fuels. This has been a driving force for new investments on solid fuel combustion technology.

Figure 4 illustrates current and potential use of forest biomass.

The current use of forest biomass in South-East Finland's heat and power plants was 1.2 TWh $(600,000$ sol$\mathrm{id} \cdot \mathrm{m}^{3}$ ) in 2010 (Figure 4). This is some $10 \%$ of forest fuel consumed in Finnish heat and power plants. 95\% of forest fuel used in South-East Finland was used by five large CHP-plants located in Kouvola (2 plants), Lappeenranta, Kotka and Rautjärvi. There are also 13 smaller district heating plants around the region using forest biomass. It is estimated that there are also some 1000 smaller (farm-scale, larger real estates, factory sheds, etc.) forest biomass users in South-East Finland [2].

The potential users (Figure 4, second pillar) of forest biomass in South-East Finland are currently using generally peat or already co-firing peat and biomass. Part of the use of peat would be transferred to solid biomass as represented earlier (see Chapter 2.1). There were totally 4 new plants in South-East Finland which could start using forest biomass and two plants could increase the current use of biomass. The potential use in existing heating and

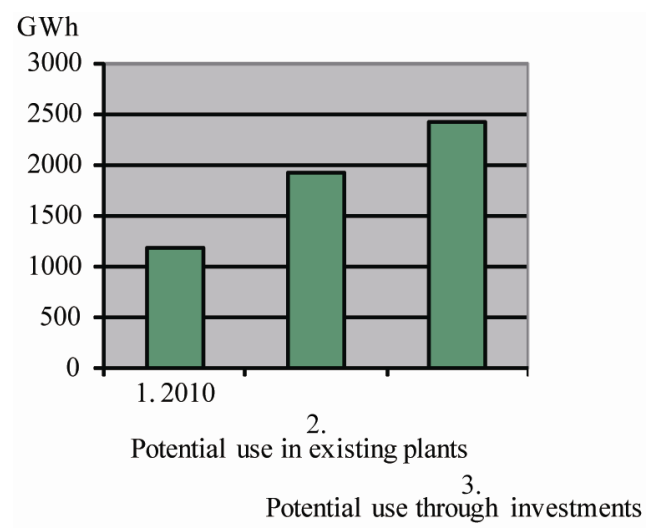

Figure 4. Current and potential use of forest biomass in South-East Finland, GWh. 
power plants is $1.9 \mathrm{TWh}\left(1.0 \mathrm{million} \operatorname{solid} \cdot \mathrm{m}^{3}\right)$.

The third potential (Figure 4, third pillar) represents theoretical amount of forest biomass that could be utilized in South-East Finland with current energy consumption structure. The amount is $2.4 \mathrm{TWh}(1.2$ million solid $\cdot \mathrm{m}^{3}$ ) and in this case investing on new combustion technology and fuel handling equipment would be necessary. In South-East Finland there are 18 possible sites which could start using solid biomass by investing on technology necessary. One of the plants is large enough to produce both heat and electricity and others would be producing heat. However, in the future situation could change and even smaller plants $\left(<5 \mathrm{MW}_{\text {fuel }}\right)$ could start producing power with renewable energy sources if electricity price or subsidies such as feed-in tariffs make it profitable. In 2011 the average price of forest fuel in Finland was approximately $18.5 € / \mathrm{MWh}$ (without VAT) [16].

Regional availability of forest biomass is represented in Figure 5. The four pillars represent different levels of regional availability of forest biomass analyzed from commercial fellings (see section 2.2).

The theoretical availability (1) represents the maximum amount of forest biomass (logging residues, stumps and small-diameter energy wood) gathered from final felling and first thinnings in South-East Finland. Second and third potential take into account technical, economical and ecological factors. The fourth potential illustrates the current availability of forest biomass in South-East Finland.

By combining the regional results represented in Figures 4 and 5 a regional forest biomass balance can be created. Balance indicates sufficiency of regional forest biomass resources and the potential areas for supplying forest biomass. The balance is useful information for local decision makers and energy sector participants when evaluating potentials for increasing the use of forest fuel. When representing these results in local level it will bring the subject closer and more concrete to local level energy participants. It is also eye-catching to see

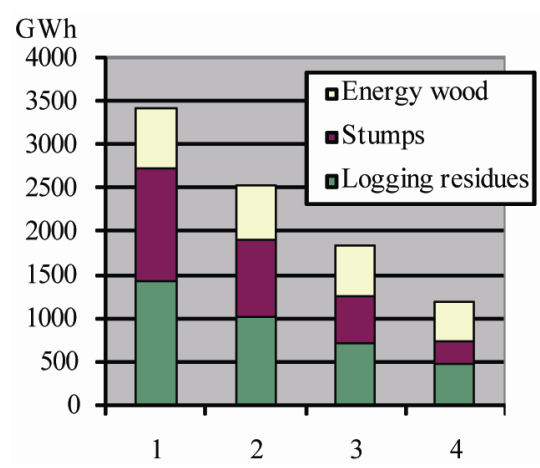

Figure 5. Regional availability of forest biomass in SouthEast Finland, GWh. current situation of forest biomass supply and demand in the area.

Current use of forest biomass in South-East Finland $(1200 \mathrm{GWh})$ is equally in balance with the availability of forest biomass when all limitations to forest biomass availability are taken into account. In this study limitations on availability were quite strict but realistic. In the future the use of forest biomass will increase in regional and local level which could create more competition on market. The regional forest biomass balance is illustrated in Figure 6.

In Figure 6 can be seen that cities with large CHPplants have negative forest biomass balance but the surrounding municipalities are usually able to satisfy their need. These plants are also multi-fuel power plants which can utilize large diversity of fuels from wood fuels and peat to natural gas and coal.

In the future there are possibilities for almost every municipality to start using solid biomass in district heating. Most suitable fuel for these is small diameter energy wood which has more uniform quality for small scale production than e.g. logging residues. Usually the availability of small diameter energy wood is high enough in local level to meet the need of local district heating plant. Challenges for the development are how to improve forest owner's willingness to sell energy wood and how to operate cost-effectively in local level.

\section{Conclusions}

This study introduced a useful method for analyzing areal supply and demand of forest biomass. Known forest biomass resources, divided between logging residues, stumps and small diameter energy wood, give the local potential on how much and where use of forest biomass could be increased. By these results the number of forestry machinery and amount of labor needed for harvesting energy wood can be evaluated as well as possibilities for new business opportunities.

Method this study introduced is suitable for local level studies discussing on utilization of forest biomass. The results can be used in regional and local level by the decision makers, investors and other participants from the field of bioenergy. Being aware of available of forest biomass and detailed information about the end users able to use solid biomass already or through investments is practical information when developing and optimizing the use of forest biomass (e.g. conventional energy production vs refining such as torrefaction or gasification) and planning the supply security of energy management.

The results can be used as an initial data for future energy strategies and scenarios, emission balances, land use planning, business strategies and for regional energy planning. Being aware of availability it is also possible to 


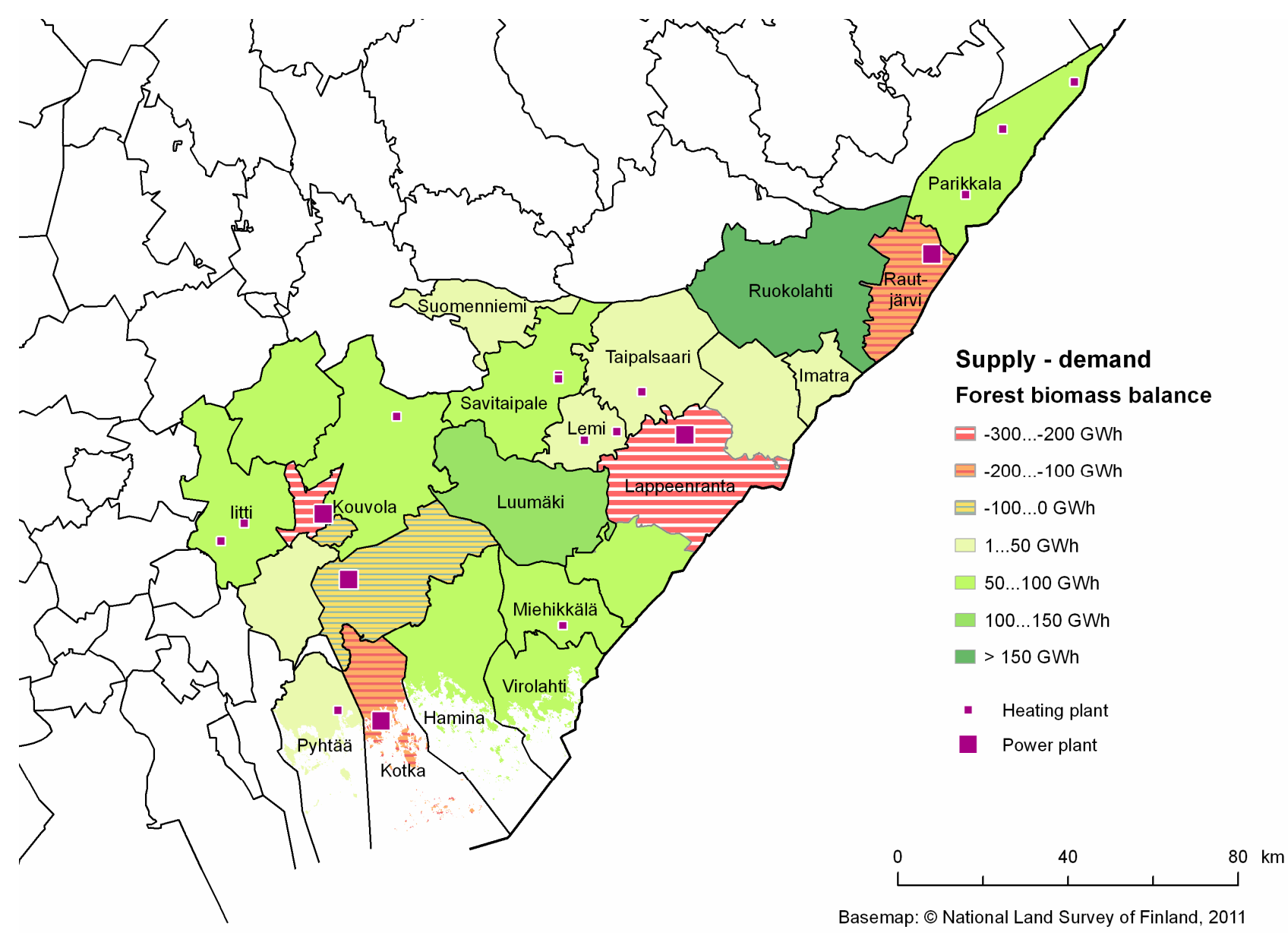

Figure 6. Balance between use and availability of forest biomass in South-East Finland.

analyze optimization of different fuel mixtures and to evaluate the profitability of them.

Today forest biomass markets in Finland are basically running around the commercial fellings of large pulp and paper companies. Logging residues and stumps are supplied to CHP-power plants by these companies through already existing supply routes. Market around small-diameter energy wood needs further development and more security because the demand of energy wood is not year-round. This is challenge for energy entrepreneurs and forest fuel suppliers because of limitations in storage capacity and flexibility in revenue.

In the future the regional demand of forest fuel will increase which will put pressure on local supply. Rising demand will be significant if investments on large-scale liquid biofuel production or gasification of biomass are made. These could shake up the whole biomass market.

By replacing the use of fossil fuels with renewable and domestic energy sources $\mathrm{CO}_{2}$-emissions and local dependency on imported fossil fuels can be reduced. However structural changes in local energy management take time and investments on energy production technologies are long-term. In the future taxation, subsidies, emission trading and competitive fuel prices are things that could hasten that process. Time will tell how soon oil and other fossil fuels will last but investments on biofuel based energy production are needed in all over the world.

\section{REFERENCES}

[1] Statistics Finland, "Energy Supply, Consumption and Prices, 2010 4th Quarter," pp. 1-11.

[2] Metla-Finnish Forest Research Institute, MetINFOForest Information Services, Official Statistics of Finland, 2011. http://www.metla.fi/metinfo/

[3] Pöyry Energy Oy. Finnish Energy Industries. "Metsäenergian Saatavuus Energiantuotantoon Eri Markkinatilanteissa," 2009, p. 13.

http://www.energia.fi/sites/default/files/et metsabioenergi aselvitysi_30042009.pdf

[4] J. Laitila, A. Asikainen and P. Anttila, "Energiapuuvarat," In: M. Kuusinen and H. Ilvesniemi, Eds., Energiapuun Korjuun Ympäristövaikutukset, Research Report. Publications of Forestry Development Centre Tapio and MetlaFinnish Forest Research Institute, 2008, pp. 8-10. www.metsavastaa.net/energiapuu/raportti

[5] K. Kärhä, J. Elo, P. Lahtinen, T. Räsänen, S. Keskinen, P. 
Saijonmaa, H. Heiskanen, M. Strandström and H. Pajuoja, "Availability and Use of Wood-Based Fuels in Finland in 2020," Publications of the Ministry of Employment and the Economy, Energy and Climate 66/2010, 2010.

[6] K. Kärhä, M. Strandström, P. Lahtinen and J. Elo, "Forest Chip Production Machinery and Labour Demand in Finland," Metsäteho Oy and Pöyry Oy, Metsätehon Katsaus 41/2009, 2009.

[7] M. Laihanen, A. Karhunen and T. Ranta, "Energy Balance of South-East Finland," Lappeenranta University of Technology, LUT Energy, 2009.

http://www.lut.fi/fi/mikkeli/bioenergy/projects/finished/K -S_balance/Sivut/Default.aspx

[8] P. Lahtinen, “Turpeen ja Puun Yhteispoltto," Pöyry Oy, Energiapäivät, Tampere, 4-5 February 2011.

[9] P. Hakkila, "Mechanized Harvesting of Stumps and Roots: A Sub-Project of the Joint Nordic Research Programme for the Utilization of Logging Residues," Finnish Forest Research Institute, Helsinki, 1972.

[10] P. Hakkila, "Summary: Crown Mass Trees at the Harvesting Phase," In: "Hakkuupoistuman Latvusmassa," Finnish Forest Research Institute, Folia Forestalia, 773,
1991.

[11] J. Repola, R. Ojansuu and M. Kukkola, "Biomass Functioned for Scots Pine, Norway Spruce and Birch in Finland," Working Papers of Finnish Forest Research Institute, 2007.

http://www.metla.fi/julkaisut/workingpapers/2007/mwp0 53.pdf

[12] K. Karttunen, J. Föhr and T. Ranta, "Energywood from South-Savo," Lappeenranta University of Technology, LUT Energy Research Report 7, 2010, p. 20.

[13] A. Simola and J. Kola, "Regional Effects of Bioenergy Production in Finland," University of Helsinki, Helsinki, 2010.

[14] O. Äijälä, M. Kuusinen and A. Koistinen, "Hyvän Metsänhoidon Suositukset Energiapuun Korjuuseen ja Kasvatukseen," Forestry Development Centre Tapio, 2010.

[15] E. Ylitalo, "Finnish Statistical Yearbook of Forestry," Metla-Finnish Forest Research Institute, Vantaa, 2010.

[16] Pöyry Oy, "Quarterly Price Follow-Up of Solid Wood Fuels,” 2011. http://www.puunhinta.fi/ 